\title{
Using Accounting Information For Financial Planning And Forecasting: An Application Of The Sustainable Growth Model Using Coca-Cola
}

John C. Gardner, University of New Orleans, USA

Carl B. McGowan, Jr., Norfolk State University, USA

Susan E. Moeller, Eastern Michigan University, USA

\begin{abstract}
The purpose of this paper is to provide a case example to teach students how to estimate a company's sustainable growth by using an extension of the DuPont System of financial analysis on Coca-Cola Corporation. The DuPont system is based on a company's return on equity that is decomposed into three components: net profit margin, total asset turnover, and the equity multiplier. The extended DuPont system of financial analysis multiplies return on equity by the earnings retention rate to calculate sustainable growth. Sustainable growth is the highest level of growth in sales that a company can achieve using internally generated funds only.
\end{abstract}

Keywords: financial analysis; financial planning; financial modeling; Coca-Cola

\section{INTRODUCTION}

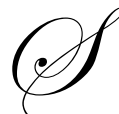

ustainable growth is the maximum rate at which a company can increase sales while maintaining the target or optimal leverage ratio without any additional external equity financing. The sustainable growth model assumes that total owners' equity for a company can only increase when retained earnings increase.

The impact of this limitation on sales growth can be derived from the fundamental equation of accounting which states that assets must be equal to liabilities plus owners' equity.

Assets $=$ Liabilities + Equity

As a result of this assumption requiring that assets equal liabilities plus owners' equity, any changes in assets must be equal to changes in liabilities plus changes in owners' equity.

$\Delta$ Assets $=\Delta$ Liabilities $+\Delta$ Equity

Further, the sustainable growth model assumes that any change in equity can only result from a change in retained earnings. Therefore, the firm cannot sell additional owners' equity.

$\Delta$ Assets $=\Delta$ Liabilities $+\Delta$ Retained Earnings

This means the company's future increase in assets is equal to the future increase in retained earnings plus the additional debt that is supported by the additional owners' equity as determined by the equity multiplier. The equity multiplier is equal to total assets divided by owners' equity. 
$\Delta$ Total Assets $=(\Delta$ Retained Earnings $)($ Equity Multiplier $)$

An increase in total revenue must be accompanied by a proportionate increase in total assets. Since any increase in total revenue is limited by the increase in total assets, growth in total revenue is limited by the increase in retained earnings. Total asset turnover is equal to sales divided by total assets.

$\Delta$ Total Revenue $=(\Delta$ Total Assets $)($ Total Asset Turnover $)$

The net income required to achieve the target return on equity is determined by total revenue times the net profit margin. Net profit margin is equal to net income divided by total revenue.

$\Delta$ Net Income $=(\Delta$ Total Revenue $)($ Net Profit Margin $)$

Earnings retention is equal to retained earnings divided by net income.

Earnings Retention $=$ Retained Earnings $/$ Net Income

Sustainable growth is equal to return on equity times the earnings retention rate of the company.

Sustainable Growth $=($ Return on Equity $)($ Earnings Retention $)$

\section{COMPUTING SUSTAINABLE GROWTH ${ }^{1}$}

The DuPont system of financial analysis is based on the return on equity model that disaggregates return on equity into three components: net profit margin, total asset turnover, and the equity multiplier. Figure 1 provides a detailed view of sustainable growth which can be used to demonstrate the interconnectedness of the financial accounts used to compute sustainable growth. The net profit margin ratio allows the financial analyst to forecast the income statement and the components of the income statement, both revenue and expenses. To achieve the target ROE requires the firm to determine the net income required to achieve the target ROE. Total revenue is predicted from the required net income based on the net profit margin ratio. Total asset turnover allows the financial analyst to forecast the left-hand side of the balance sheet: assets. The firm uses the total revenue projection to predict total asset requirements. Based on the firm's operating leverage, corporate managers can determine the ratio of current assets to total assets and the composition of assets. The equity multiplier allows the financial analyst to forecast the right-hand side of the balance sheet since liabilities and owners' equity must equal total assets. The corporation must issue debt so that the leverage ratio remains constant. From the DuPont system of financial analysis, the company is able to develop pro forma financial statements, particularly, the income statement and the balance sheet.

The DuPont system of financial analysis fulfills three functions. First, the DuPont system allows the firm to project future operations through the pro forma financial statements developed as a budget or financial plan. The second function performed by the DuPont system is as a control mechanism. As the firm progresses through the year, the firm can use the pro forma financial statements to monitor performance. If the firm's operating performance deviates from the budget, the firm can take corrective action. If the deviation is negative, managers can correct the problem or adjust their forecasts. If the deviation is positive, managers can analyze and potentially enhance the positive change. The third function of the DuPont system is in the post-performance audit function. After the planning year ends, the firm can compare actual operating performance with planned operating performance to determine the deviation from the plan. In the long-term, effective performance budgeting should result in the deviation from the budget being near zero. Otherwise, the firm will be under-budgeting or overbudgeting.

\footnotetext{
1 See Brigham, Eugene F. and Michael C. Ehrhardt. Financial Management, Theory and Practice, Twelth Edition, Thomson/Southwestern, Mason, OH, 2008 and/or Ross, Stephen A., Randolph W. Westerfield, and Bradford D. Jordan. Fundamentals of Corporate Finance, Eighth Edition, McGraw-Hill Irwin, New York, 2008 for a detailed discussion of the DuPont system of financial analysis.
} 
Return on equity analysis provides a system for planning and for analyzing a company's performance. The net profit margin allows the analyst to develop a pro forma income statement, as in Figure 2. The top box of Figure 2 shows an abbreviated income statement where net income is equal to revenues minus expenses. Given a target ROE, the financial manager can determine the net income needed to achieve the target ROE. From the target ROE, the financial manager can determine the revenue level necessary to achieve the net income target. The middle box of Figure 2 shows how the financial manager can use the total asset turnover ratio to project the total asset level necessary to generate the projected revenue level. Given a level of projected revenue, the financial manager can project the level of total assets needed to produce the projected level of revenues. The total asset requirement to project the pro forma levels of all of the asset accounts. The fundamental equation of accounting is that assets equal liabilities plus owners equity. The bottom box of Figure 2 shows how the financial manager uses the equity multiplier ratio to project the pro forma financial needs and the financial structure of the company. Total liabilities and equity must be equal to the projected total asset requirements.

This model is called the DuPont system of financial analysis and the extended DuPont System is used to compute sustainable growth ${ }^{2}$. Sustainable growth, G, is equal to ROE times the retention rate which is one minus the payout ratio.

$\mathrm{G} \quad=\mathrm{ROE}(\mathrm{RR})$

$=($ Net Income/Owners Equity $)(1-D i v i d e n d s /$ Net Income $)$

Sustainable growth is the maximum growth rate that the firm can achieve without additional external financing beyond what is justified by the growth in retained earnings. The sustainable growth model assumes that the firm will maintain the target capital structure. The target capital structure will be the capital structure that minimizes the weighted average cost of capital for the firm that maximizes the value of the firm.

\section{ANALYSIS OF ROE AND SUSTAINABLE GROWTH FOR COCA-COLA}

Table 1 contains the data and ratios for the DuPont system financial analysis of return on equity and the analysis of sustainable growth for Coca-Cola based on the annual data for the years from 2000 to 2007. The first five lines from total revenue to dividends contain the raw data needed to compute the ratios used in the DuPont system of financial analysis and for the sustainable growth rate. Over the period from 2000 to 2007, total revenue for Coca-Cola increased from $\$ 17,354$ billion to $\$ 28,857$ billion. Total revenue for Coca-Cola increased every year over the sample period. Net income rose from $\$ 2,177$ billion to $\$ 5,981$ billion dollars and increased every year. Total assets rose from $\$ 21,623$ to $\$ 43,269$ but did not increase every year, i.e. total assets declined in both 2001 and 2005. Total owners' equity rose from $\$ 9,513$ billion in 2000 to $\$ 3,149$ in 2007 . Total owners' equity rose every year. Dividends rose from $\$ 1,685$ in 2000 to $\$ 3,149$ in 2007 . Dividends rose every year.

The next four lines in Table 1 contain net profit margin, NPM, total asset turnover, TAT, the equity multiplier, EM, and the earnings retention rate, RR, which are the ratios needed to compute return on equity, ROE, and sustainable growth, G. ROE is computed by two methods. The first line of ROE is computed by dividing net income by total owners' equity. The second line of ROE is computed by multiplying NPM by TAT by EM. If the two computations for ROE are the same, then the analysis is correct and is verified. The last line in Table 1 is the value of sustainable growth, $\mathrm{G}$, and is calculated by multiplying sustainable growth by the dividend retention rate.

The net profit margin rises from 12.54 percent in 2000 to 20.73 percent in 2007. The highest NPM is 22.63 percent in 2003 and the lowest NPM is in 2000. The average NPM is 19.60 percent. The total asset turnover is 0.80 in 2000 and falls to 0.6915 in 2004 before rising to 0.80 in 2006 and falling to 0.6669 in 2007. The average TAT is 0.7696. TAT is the most volatile of the three variables affecting ROE. The equity multiplier is 2.27 in 2000 and falls to 1.77 in 2006 and rises to 1.99 in 2007. The average EM is 2.0064. ROE is as low as 0.228 in 2000 and as high as 0.4260 in 2001 but is approximately 0.30 over the remaining sample period and averages 0.2999 for the entire analysis period.

\footnotetext{
${ }^{2}$ See Brigham and Ehrhardt (2008, page 140) and/or Ross, Westerfield, and Jordan (2008, pages 105-106) for a discussion of the DuPont system of financial analysis for a discussion of sustainable growth.
} 
The dividend retention rate averages 0.4343 over the entire analysis period with a low value of 0.2288 in 2000 and a high value of 0.5488 in 2001. Sustainable growth is lowest in 2000 at 5.17 percent and highest in 2001 at 23.38 percent. Average sustainable growth is 13.43 percent and varies between 12.8 percent and 15.48 percent from 2003 to 2007.

Graph 1 shows the variables needed to compute ROE: NPM, TAT, and EM. Graph 1 shows that NPM and EM are relatively stable but that TAT declines over the analysis period. Thus, except for 2001, ROE is relatively stable averaging 13.43 percent. Graph 2 shows sustainable growth for Coca-Cola and ROE and RR which are used to compute G. The retention rate and sustainable growth rate are stable from 2003 to 2007.

\section{SUMMARY AND CONCLUSIONS}

Sustainable growth is the maximum rate at which a company can grow while maintaining the target or optimal financial leverage rate without additional external equity financing. Assets can only increase by the amount of retained earnings in the firm plus the additional debt that can be supported by the additional equity. In this paper, we demonstrate how to compute sustainable growth for Coca-Cola for the period from 2000 to 2007 and discuss the impact of the different variables on sustainable growth for Coca-Cola.

This paper uses actual financial data for Coca-Cola Corporation to do the financial analysis. As a class project, students are required to collect data for Coca-Cola, enter the data into an Excel spreadsheet, and analyze the data including graphing the data. If students are required to resent their results in a Power Point presentation, this case analysis meets several course objectives and program goals for a student majoring in accounting or finance: collecting data, entering data into a spreadsheet, manipulating the data to compute financial ratios, graphing the data, and doing a Power Point based oral presentation. Additionally, the student can be required to write a short paper on the results.

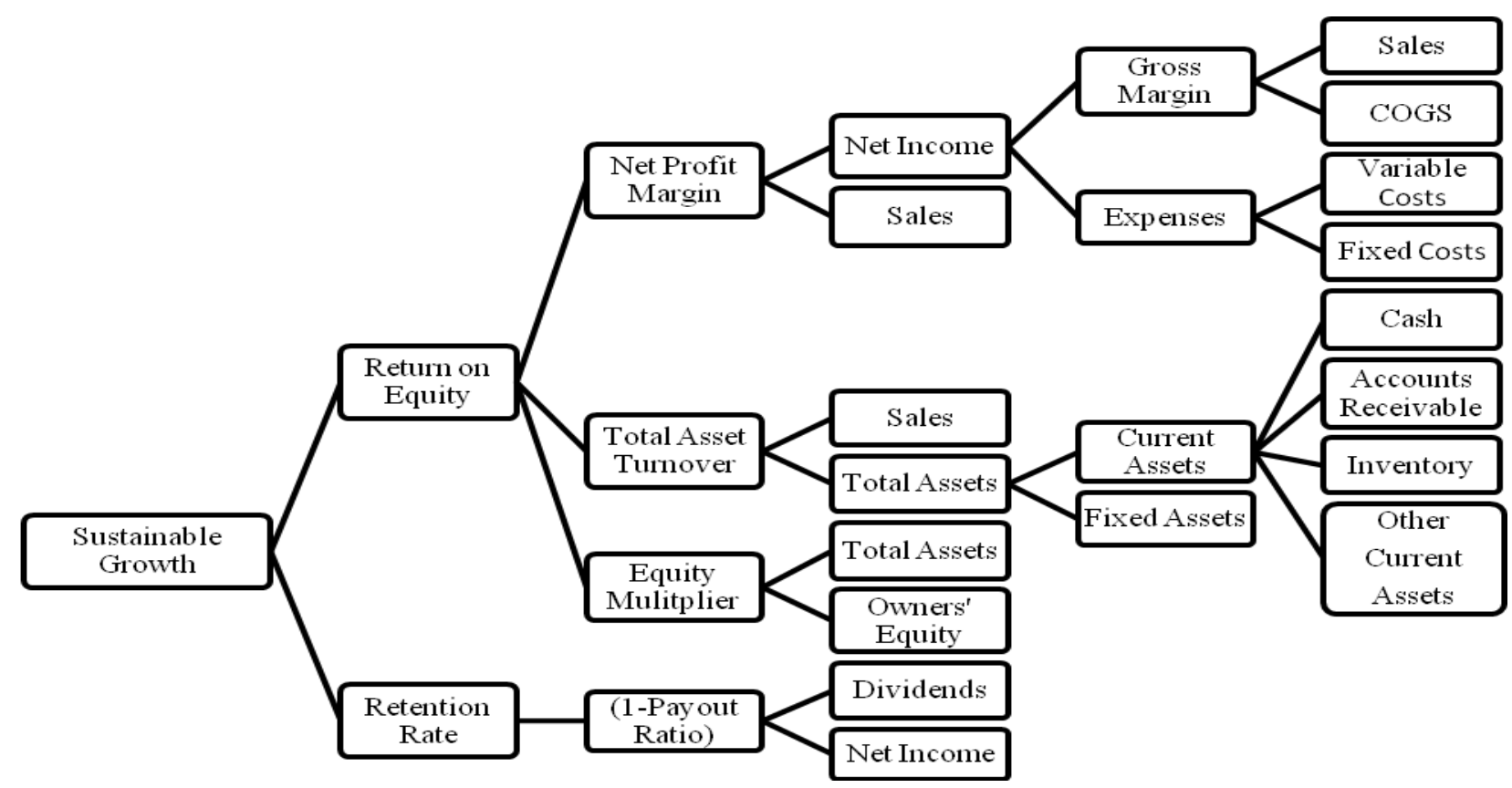

Figure 1

Sustainable Growth Model 


\begin{tabular}{rl|}
$\mathbf{N P M}=$ & $(\mathbf{N I})(\mathbf{S})$ \\
& Sales \\
& $\frac{- \text { Total Costs }}{\text { Net Income }}$ \\
\hline
\end{tabular}

\begin{aligned} & TAT $=(\mathbf{S})(\mathbf{T A}) \\ &$ Current Assets \\ &$\frac{+ \text { Fixed Assets }}{\text { Total Assets }} \\ &$\hline\end{aligned}

\begin{tabular}{|l|}
$\mathbf{E M}=(\mathbf{T A})(\mathbf{O E})$ \\
$\quad$ Total Liabilities \\
$\quad+$ Total Equity \\
\hline Total Liabilities + Owners' Equity
\end{tabular}

Figure 2

Using the DuPont System of Financial Analysis to Develop Pro Forma Financial Statements

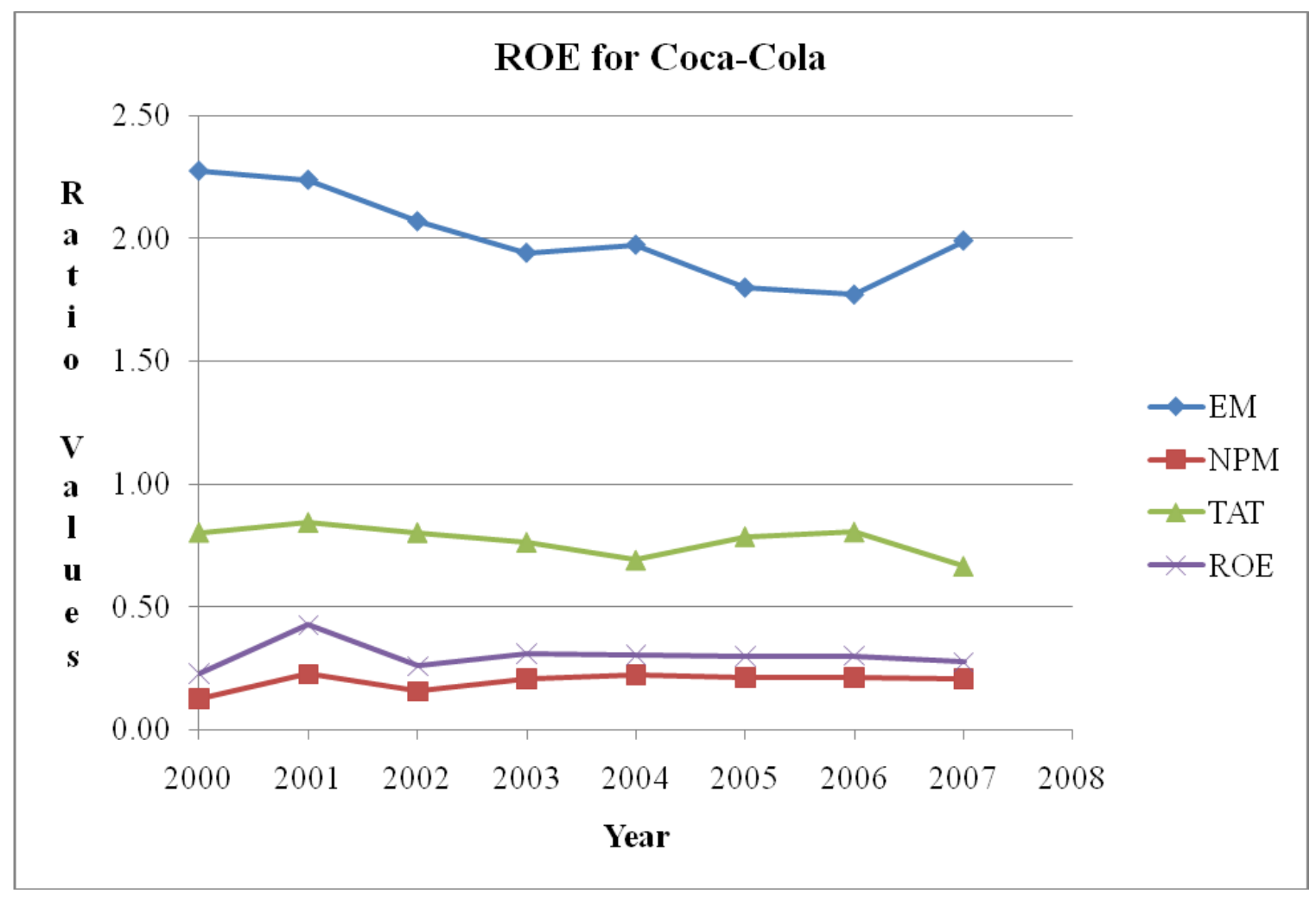

Figure 3 


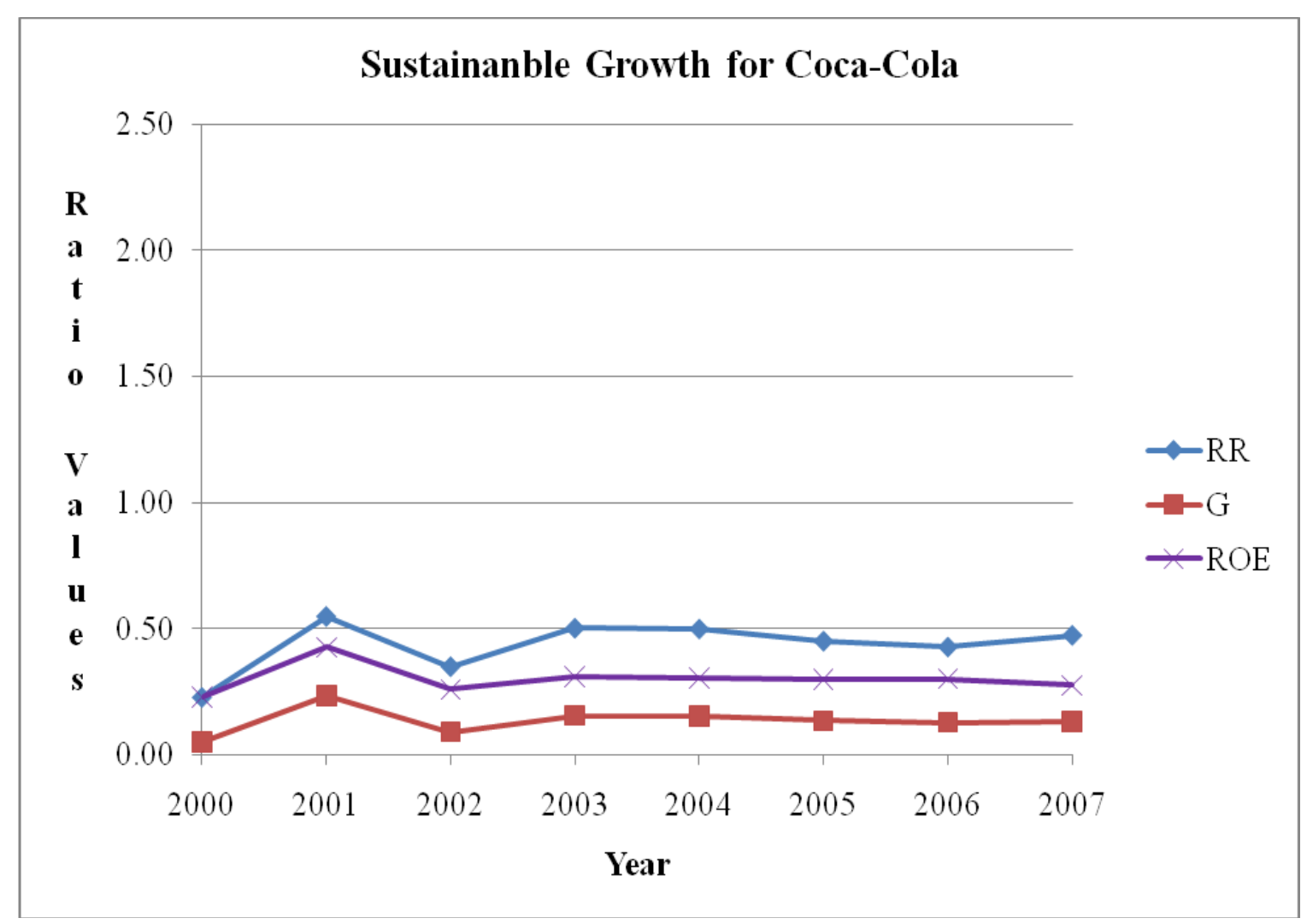

Figure 4

Table 1

Sustainable Growth for Coca-Cola

\begin{tabular}{|c|c|c|c|c|c|c|c|c|c|}
\hline Coca-Cola & 2000 & 2001 & 2002 & 2003 & 2004 & 2005 & 2006 & 2007 & Average \\
\hline Total Revenue & 17354 & 17545 & 19564 & 20857 & 21742 & 23104 & 24088 & 28857 & 21639 \\
\hline Net Income & 2177 & 3969 & 3050 & 4347 & 4847 & 4872 & 5080 & 5981 & 4290 \\
\hline Total Assets & 21623 & 20834 & 24406 & 27342 & 31441 & 29427 & 29963 & 43269 & 28538 \\
\hline Total OE & 9513 & 9316 & 11800 & 14090 & 15935 & 16355 & 16920 & 21744 & 14459 \\
\hline Dividends & 1685 & 1791 & 1987 & 2166 & 2429 & 2678 & 2911 & 3149 & 2350 \\
\hline Coca-Cola & 2000 & 2001 & 2002 & 2003 & 2004 & 2005 & 2006 & 2007 & Average \\
\hline NPM & 0.1254 & 0.2262 & 0.1559 & 0.2084 & 0.2229 & 0.2109 & 0.2109 & 0.2073 & 0.1960 \\
\hline TAT & 0.8026 & 0.8421 & 0.8016 & 0.7628 & 0.6915 & 0.7851 & 0.8039 & 0.6669 & 0.7696 \\
\hline EM & 2.2730 & 2.2364 & 2.0683 & 1.9405 & 1.9731 & 1.7993 & 1.7709 & 1.9899 & 2.0064 \\
\hline RR & 0.2260 & 0.5488 & 0.3485 & 0.5017 & 0.4989 & 0.4503 & 0.4270 & 0.4735 & 0.4343 \\
\hline ROE & 0.2288 & 0.4260 & 0.2585 & 0.3085 & 0.3042 & 0.2979 & 0.3002 & 0.2751 & 0.2999 \\
\hline ROE & 0.2288 & 0.4260 & 0.2585 & 0.3085 & 0.3042 & 0.2979 & 0.3002 & 0.2751 & 0.2999 \\
\hline $\mathrm{G}$ & 0.0517 & 0.2338 & 0.0901 & 0.1548 & 0.1517 & 0.1341 & 0.1282 & 0.1302 & 0.1343 \\
\hline
\end{tabular}




\section{AUTHOR INFORMATION}

John C. Gardner is the KPMG Professor of Accounting in the Department of Accounting at the University of New Orleans. He earned his undergraduate degree in accounting from SUNY at Albany, and MBA and Ph.D. degrees in finance from Michigan State University. Dr. Gardner has published in leading accounting, finance and management science journals including The Accounting Review, Journal of Accounting Research, Contemporary Accounting Research, Accounting, Organizations and Society, Journal of Financial and Quantitative Analysis and Decision Sciences. His research interests include multi-national corporation financial management, capital structure, and financial and forensic accounting. E-mail: jcgard@uno.edu

Carl B. McGowan, Jr., PhD, CFA is a Professor of Finance at Norfolk State University, has a BA in International Relations (Syracuse), an MBA in Finance (Eastern Michigan), and a PhD in Business Administration (Finance) from Michigan State. From 2003 to 2004, he held the RHB Bank Distinguished Chair in Finance at the Universiti Kebangsaan Malaysia and has taught in Cost Rica, Malaysia, Moscow, Saudi Arabia, and The UAE. Professor McGowan has published in numerous journals including American Journal of Business Education, Applied Financial Economics, Decision Science, Financial Practice and Education, The Financial Review, International Business and Economics Research Journal, The International Review of Financial Analysis, The Journal of Applied Business Research, The Journal of Business Case Studies, The Journal of Diversity Management, The Journal of Real Estate Research, Managerial Finance, Managing Global Transitions, The Southwestern Economic Review, and Urban Studies. E-mail: mcgowan@nsu.edu

Susan E. Moeller is a Professor of Finance at Eastern Michigan University since 1990. Prior to joining EMU, Dr. Moeller taught at Northeastern University in Boston and at the University of Michigan - Flint. Her corporate experience was with Ford Motor Company. She has published in a number of journals including, American Journal of Business Education, Journal of Economic and Financial Education, Journal of Business Case Studies, Journal of Global Business, Journal of International Finance, Journal of Financial and Strategic Decisions, Management International Review, Journal of Applied Business Research and AAII Journal. E-mail: smoeller@emich.edu

\section{REFERENCES}

1. Brigham, Eugene F. and Michael C. Ehrhardt. Financial Management, Theory and Practice, Twelfth Edition, Thomson/Southwestern, Mason, OH, 2008.

2. Damodaran, Aswath. “Applied Corporate Finance," Second Edition, John Wiley\& Sons, Inc., 2006.

3. Graham, John R. and Campbell R. Harvey. "The Theory and Practice of Corporate Finance: Evidence from the Field," Journal of Financial Economics, 2002, pp. 187-243.

4. http://nobelprize.org/nobel_prizes/economics/laureates/1990/press.html

5. Ross, Stephen A., Randolph W. Westerfield, and Bradford D. Jordan. Fundamentals of Corporate Finance, Eighth Edition, McGraw-Hill Irwin, New York, 2008.

6. William R. Sharpe, Capital Asset Prices: A Theory of Market Equilibrium under Conditions of Risk, The Journal of Finance, September 1964, pp. 425-552.

7. Stocks, Bonds, Bills, and Inflation, Market Results for 1926 -2006, 2007 Yearbook, Classic Edition, Morningstar, 2007. 


\section{NOTES}

